Article

\title{
An Enzymatic Flow-Based Preparative Route to Vidarabine
}

\author{
Lucia Tamborini ${ }^{1, *}$, Clelia Previtali ${ }^{1}$, Francesca Annunziata ${ }^{1}$, Teodora Bavaro ${ }^{2}$, \\ Marco Terreni ${ }^{2}$, Enrica Calleri ${ }^{2}$, Francesca Rinaldi ${ }^{2}$, Andrea Pinto ${ }^{3}\left(\mathbb{D}\right.$, Giovanna Speranza ${ }^{4}$, \\ Daniela Ubiali $^{2, *(\mathbb{O})}$ and Paola Conti ${ }^{1}$
}

1 Department of Pharmaceutical Sciences, University of Milan, via Mangiagalli 25, 20133 Milano, Italy; clelia.previtali@unimi.it (C.P.); francesca.annunziata@unimi.it (F.A.); paola.conti@unimi.it (P.C.)

2 Department of Drug Sciences, University of Pavia, viale Taramelli 12, 27100 Pavia, Italy; teodora.bavaro@unipv.it (T.B.); marco.terreni@unipv.it (M.T.); enrica.calleri@unipv.it (E.C.); francesca.rinaldi01@universitadipavia.it (F.R.)

3 Department of Food, Environmental and Nutritional Sciences, University of Milan, via Celoria 2, 20133 Milano, Italy; andrea.pinto@unimi.it

4 Department of Chemistry, University of Milan, via Golgi 19, 20133 Milano, Italy; giovanna.speranza@unimi.it

* Correspondence: lucia.tamborini@unimi.it (L.T.); daniela.ubiali@unipv.it (D.U.); Tel.: +39-02-50319367 (L.T.); +39-0382-987889 (D.U.)

Academic Editors: Antimo Gioiello and Bruno Cerra

Received: 3 February 2020; Accepted: 7 March 2020; Published: 9 March 2020

\begin{abstract}
The bi-enzymatic synthesis of the antiviral drug vidarabine (arabinosyladenine, ara-A), catalyzed by uridine phosphorylase from Clostridium perfringens (CpUP) and a purine nucleoside phosphorylase from Aeromonas hydrophila (AhPNP), was re-designed under continuous-flow conditions. Glyoxyl-agarose and EziG ${ }^{\mathrm{TM}} 1$ (Opal) were used as immobilization carriers for carrying out this preparative biotransformation. Upon setting-up reaction parameters (substrate concentration and molar ratio, temperature, pressure, residence time), $1 \mathrm{~g}$ of vidarabine was obtained in $55 \%$ isolated yield and $>99 \%$ purity by simply running the flow reactor for 1 week and then collecting (by filtration) the nucleoside precipitated out of the exiting flow. Taking into account the substrate specificity of $C p \mathrm{UP}$ and $A h \mathrm{PNP}$, the results obtained pave the way to the use of the $C p \mathrm{UP} / A h \mathrm{PNP}$-based bioreactor for the preparation of other purine nucleosides.
\end{abstract}

Keywords: flow bioreactor; enzyme immobilization; nucleoside phosphorylase; vidarabine; nucleosides

\section{Introduction}

The use of biocatalysis in multiple industrial sectors is rapidly expanding due to the several benefits that it offers over traditional chemo-catalytic methods. Enzyme-catalyzed reactions are selective, safe, and environmentally friendly, thus meeting the increasing demand of industry for more efficient and sustainable processes [1,2]. However, low productivity and difficult product downstream are still the most often encountered bottlenecks in biocatalysis, which limit the implementation of enzymatic processes in industry [3]. Continuous flow technology is emerging as a key enabling tool for biocatalytic process intensification [4-8]. Flow processing has the potential to accelerate heterogeneous biotransformations due to biocatalyst high local concentration and enhanced mass transfer, making large-scale production more economically feasible in small equipment, with a substantial decrease in reaction time and improvement in space-time yield. Moreover, biocatalyst stability can benefit from an environment where harsh mixing is avoided. A further advantage of flow reactors is that their configuration can be easily customized to meet the specific requirements of the biotransformation. 
In this frame, the addition of in-line purification steps can assist the downstream process, also reducing time and costs associated with this often troublesome step. Methods based on the use of biotransformations in continuous flow reactors appear to be suitable for the intensification of industrially relevant processes, such as the synthesis of active pharmaceutical ingredients (APIs) [4,9].

Despite the enormous progress in nucleoside chemistry, the obtainment of nucleoside analogues is still a synthetic challenge $[10,11]$. Due to the exquisite selectivity of enzymes, the introduction of one or more biocatalytic steps in synthetic sequences has been demonstrated to simplify the preparation of these molecules, by cutting the number of reaction steps and avoiding by-product formation. Process intensification by flow reactor technology would be desirable to take another step forward in the full exploitation of enzyme-based reactions for the synthesis of nucleoside analogues.

Enzymes of nucleic acid metabolism, such as nucleoside phosphorylases (NPs, EC 2.4.2), have been conveniently used as biocatalysts in the synthesis of a number of nucleoside analogues [12-16]. These enzymes catalyze the reversible cleavage of the glycosidic bond of (deoxy)ribonucleosides in the presence of inorganic phosphate (Pi) to generate the nucleobase and $\alpha$-D-(deoxy)ribose-1-phosphate (phosphorolysis). If a second nucleobase is added to the reaction medium, the formation of a new nucleoside can result (transglycosylation).

In this context, we focused our attention on the study of the flow biocatalyzed transglycosylation reaction to obtain nucleoside analogues of pharmaceutical interest, such as vidarabine (arabinosyladenine, ara-A). To achieve this, we used recombinant uridine phosphorylase from Clostridium perfringens (C $p \mathrm{UP})$ and a purine nucleoside phosphorylase from Aeromonas hydrophila (AhPNP), an enzymatic twosome that has been successfully applied to the synthesis of both vidarabine ("one-pot, two-enzyme" transglycosylation) [17] and vidarabine-5'-monophosphate, in a batch mode ("one-pot, three-enzyme" transglycosylation and phosphorylation) [18].

\section{Results and Discussion}

With the aim to fully exploit the potential of the target biocatalyzed reaction in flow, we carried out a study on the co-immobilization of AhPNP and C $p$ UP on two hydrophilic supports, i.e., glyoxyl-agarose (GA) and EziG ${ }^{\mathrm{TM}} 1$ (Opal) $[19,20]$, which involve a different binding chemistry between the enzymes and the support (Scheme 1). Both carriers were packed into an Omnifit glass column and the enzymes were then immobilized by flowing a solution of the proteins through it. The obtained bioreactors, characterized in terms of immobilization yield and recovered activity, were used to perform the transglycosylation reaction in a continuous-flow mode. Parameters of the transglycosylation reaction (e.g., substrate concentration, molar ratio, temperature, pressure, residence time) have been screened for the highest yield and productivity. An array of substrates was tested to demonstrate the versatility of the synthetic approach and then to prepare the antiviral drug vidarabine on a gram scale. The manufacturing process was implemented by adding an in-line purification step for vidarabine to facilitate work-up and product recovery. 
a) Covalent immobilization on glyoxyl-agarose

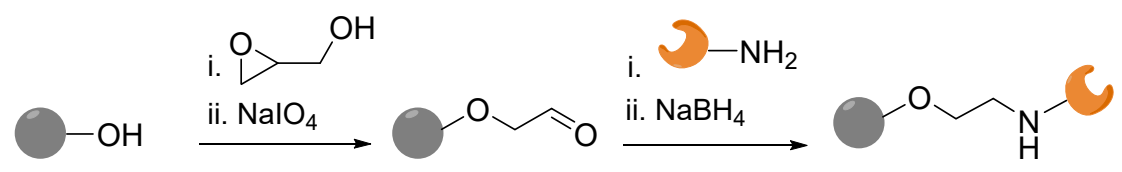

b) Immobilization on EziG1(Opal) by coordination bonds

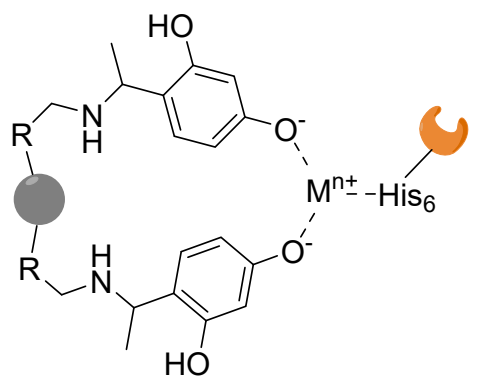

Scheme 1. General scheme of the immobilization reactions discussed in the text. $\mathrm{M}^{\mathrm{n}+}=$ metal ion of the CPG carrier (controlled pore glass) $\mathrm{EziG}^{\mathrm{TM}} 1$ (Opal) (e.g., $\mathrm{Fe}^{3+}, \mathrm{Co}^{2+}$ ); $\mathrm{His}_{6}=$ six-histidine tag.

\subsection{Immobilization on Glyoxyl-Agarose under Continuous Flow}

The flow immobilization of each enzyme was first studied separately. CpUP was immobilized first, reproducing the batch conditions previously reported [21]. To mimic the batch conditions (i.e., $3 \mathrm{~h}$ at room temperature), the buffer containing C $p \mathrm{UP}$ (50 mM sodium carbonate $\mathrm{pH} 10$, protein loading 5 $\mathrm{mg}$ per gram of carrier) was flowed for $3 \mathrm{~h}$ through the column (glass column i.d.: $6.6 \mathrm{~mm}$; length: $100 \mathrm{~mm})$ packed with glyoxyl-agarose $(0.68 \mathrm{~g}$, reactor volume: $0.68 \mathrm{~mL})$ using a recirculation system; this step was followed by the chemical reduction of the newly formed imino bonds with a solution of $\mathrm{NaBH}_{4}$ recirculating for $30 \mathrm{~min}$. Under these conditions, both yield and recovered activity of the immobilized protein were consistent with the results obtained in the in batch immobilization (100\% and $35 \%$, respectively). The activity of imm-CpUP was determined spectrophotometrically by monitoring the phosphorolysis of 2'-deoxyuridine to uracil, after withdrawing the immobilized enzyme from the column. Then, the protocol was repeated by decreasing the immobilization time from $3 \mathrm{~h}$ to $1 \mathrm{~h}$ and the reduction step from $30 \mathrm{~min}$ to $15 \mathrm{~min}$. The immobilized yield aligned with the previous results $(100 \%)$, and the recovered activity was retained (34\%).

Immobilization of $A h P N P$ resulted to be troublesome. In fact, under the same conditions as for C $p$ UP, the percentage of immobilized protein was less than a half (40\%) and the recovered activity was only $14 \%$. The immobilization was performed by recirculating a solution of the free enzyme (5 mg per gram of carrier) in $50 \mathrm{mM}$ sodium carbonate buffer $\mathrm{pH} 10$ containing hypoxanthine $(5 \mathrm{mM})$ and glycerol $(20 \% \mathrm{v} / \mathrm{v})$. Again, the reduction of the imino bonds was performed with a solution of $\mathrm{NaBH}_{4}$ recirculating for $30 \mathrm{~min}$.

Each immobilized enzyme recovered from the respective column was submitted to a stability test. Both C $p$ UP and AhPNP were incubated for $24 \mathrm{~h}$ under mechanical stirring in $50 \mathrm{mM}$ carbonate buffer at $\mathrm{pH} 10$. The enzyme activity was then evaluated after 3,6 and $24 \mathrm{~h}$ and, whereas imm-CpUP resulted to be stable, imm-AhPNP showed a loss of activity (about $85 \%$ after $24 \mathrm{~h}$ ). Furthermore, both enzymes were incubated separately for $15 \mathrm{~min}$ at $95{ }^{\circ} \mathrm{C}$ in the presence of a denaturing agent, i.e., 2-mercaptoethanol; the stability of the immobilized enzymes was not affected in this case.

A flow protocol to evaluate the activity of the immobilized enzymes was also developed with the aim to have a straightforward method for assessing their activity without the need for "un-packing" the biocatalysts. In both cases, the phosphorolysis of the reference substrate (i.e., inosine for AhPNP and $2^{\prime}$-deoxyuridine for $C p U P$ ) was monitored to determine the residual activity upon immobilization. Therefore, a solution of inosine $(20 \mathrm{mM})$ or a solution of $2^{\prime}$-deoxyuridine $(20 \mathrm{mM})$ in $50 \mathrm{mM}$ phosphate 
buffer $\mathrm{pH} 7.5$ was pumped through the respective bioreactor and the exiting solution was collected and analyzed by HPLC. The percentage of phosphorolysis was calculated based on the depletion of the nucleoside, by monitoring the formation of the nucleobase (i.e., hypoxanthine and uracil, respectively; see Materials and Methods, Section 3.1).

Once the in-flow immobilization for each enzyme was evaluated, a protocol for the in-flow co-immobilization of the two enzymes was investigated. Given the issues concerning AhPNP immobilization, we decided to immobilize it first, followed by CpUP (protein loading: $7 \mathrm{mg}$ of $A h \mathrm{PNP}$ and $3 \mathrm{mg}$ of C $p \mathrm{UP}$ per gram of carrier), under the conditions reported above. From protein measurements of the exiting flow solution [22], immobilization yields resulted to be almost quantitative for $C p \mathrm{UP}$ and $58 \%$ for AhPNP. After chemical reduction, the recovered activity was $40 \%$ for $C p \mathrm{UP}$ and $14 \%$ for $A h \mathrm{PNP}$.

\subsection{Transglycosylation Reaction Using Glyoxyl-Agarose-Based CpUP/AhPNP-Bioreactor}

The $C p \mathrm{UP} / A h \mathrm{PNP}$-bioreactor (reactor volume: $0.68 \mathrm{~mL}$ ) was tested in the synthesis of adenosine (7, Scheme 2$)$ by transglycosylation reaction using uridine (1) as the sugar donor $(4 \mathrm{mM})$ and adenine (5) as the nucleobase $(2 \mathrm{mM})$ in $50 \mathrm{mM}$ phosphate buffer $\mathrm{pH}=7.5$. These experimental conditions (i.e., buffer, substrate concentration and ratio, $\mathrm{pH}$ ) were selected from previously reported studies in batch [21]. The solution containing the sugar donor and the sugar acceptor were pumped through the bioreactor pressurized at 20 psi.

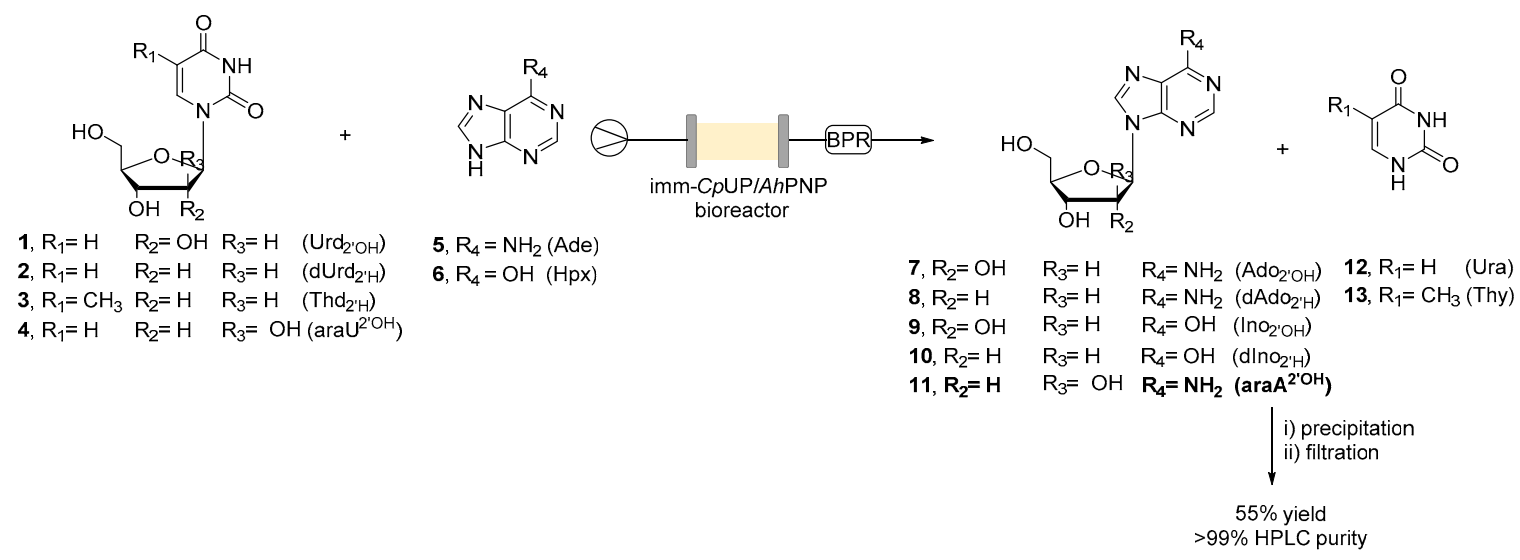

Scheme 2. General scheme of the flow biocatalyzed transglycosylation reactions. BPR: backpressure regulator (20 psi). Legend: $\operatorname{Urd}_{2^{\prime} \mathrm{OH}}\left(1\right.$, uridine), $\operatorname{dUrd}_{2^{\prime} \mathrm{H}}\left(2,2^{\prime}\right.$-deoxyuridine), $\operatorname{Thd}_{2^{\prime} \mathrm{H}}$ (3, thymidine), $\operatorname{araU}^{2^{\prime} \mathrm{OH}}$ (4, arabinofuranosyluracil), Ade (5, adenine), $\mathrm{Hpx}$ (6, hypoxanthine), $\mathrm{Ado}_{2^{\prime} \mathrm{OH}}(7$, adenosine), $\mathrm{dAdo}_{2^{\prime} \mathrm{H}}\left(\mathbf{8}, 2^{\prime}\right.$-deoxyadenosine), $\mathrm{Ino}_{2^{\prime} \mathrm{OH}}$ (9, inosine), dino $2^{\prime} \mathrm{H}$ (10, 2'-deoxyinosine), araA ${ }^{2^{\prime} \mathrm{OH}}$ (11, arabinosyladenine, vidarabine), Ura (12, uracil), Thy (13, thymine).

Different residence times and substrate concentrations were screened (Table 1). In only 5 min of residence time, an $85 \%$ conversion was achieved, as determined by HPLC (Table 1, entry 1). Then, to increase the productivity of the process, the concentration of the sugar donor was set to $100 \mathrm{mM}$, keeping constant the 2:1 ratio to the sugar acceptor. Interestingly, also at the highest tested concentration (Table 1, entry 10), an $89 \%$ conversion was obtained in only $5 \mathrm{~min}$. However, due to the poor water solubility of the substrates, the addition of a co-solvent (i.e., DMF) in the range $10-20 \%$ v/v was necessary (see Table 1). DMF was selected as the co-solvent according to the stability studies previously carried out in the batch mode transglycosylation [17]. An increase of the residence time up to 20 min (Table 1, entries 3 and 4) did not lead to a higher conversion. Then, using the highest concentration that does not require any co-solvent (i.e., $16 \mathrm{mM}$ uridine, $8 \mathrm{mM}$ adenine), a further decrease of the residence time was evaluated. The reaction reached the equilibrium after only $1 \mathrm{~min}$ of residence time (Table 1 , entry 7). Finally, an increase of the temperature (up to $38^{\circ} \mathrm{C}$ ) and different molar ratios between the sugar 
donor and the sugar acceptor (1:1 and 4:1) were also tested but, in all cases, no beneficial effects were observed (data not shown).

Table 1. Synthesis of adenosine (7) by continuous flow transglycosylation reaction catalyzed by co-immobilized $C p \mathrm{UP}$ and AhPNP: screening of the reaction conditions.

\begin{tabular}{|c|c|c|c|c|}
\hline Entry & Residence Time (min) & [Urd, 1] (mM) & [Ade, 5] (mM) & Conversion (\%) ${ }^{a}$ \\
\hline 1 & 5 & 4 & 2 & 85 \\
\hline 2 & 5 & 8 & 4 & 86 \\
\hline 3 & 10 & 8 & 4 & 84 \\
\hline 4 & 20 & 8 & 4 & 84 \\
\hline 5 & 5 & 16 & 8 & 86 \\
\hline 6 & 2.5 & 16 & 8 & 86 \\
\hline 7 & 1 & 16 & 8 & 86 \\
\hline $8^{b}$ & 5 & 32 & 16 & 88 \\
\hline $9^{b}$ & 5 & 40 & 20 & 89 \\
\hline $10^{\mathrm{c}}$ & 5 & 100 & 50 & 89 \\
\hline
\end{tabular}

${ }^{a}$ Determined by HPLC: [product area/(product area + substrate area)] $\times 100$. Conversions $(\%)$ are the average of two experiments. ${ }^{\mathrm{b}} \mathrm{DMF}(10 \% v / v)$ was added as the co-solvent. ${ }^{\mathrm{c}} \mathrm{DMF}(20 \% v / v)$ was added as the co-solvent. Experimental conditions: $50 \mathrm{mM}$ phosphate buffer $\mathrm{pH} 7.5 ; \mathrm{T}=28^{\circ} \mathrm{C} ; \mathrm{P}=20 \mathrm{psi}$.

The stability of the bioreactor under continuous work was tested in the conditions reported in Table 1, entry 7 (reactor volume: $0.68 \mathrm{~mL}$; residence time: $1 \mathrm{~min} ; \mathrm{T}=28^{\circ} \mathrm{C} ; \mathrm{P}=20 \mathrm{psi} ; 16 \mathrm{mM}$ uridine (1); $8 \mathrm{mM}$ adenine (5); flow stream: $50 \mathrm{mM}$ phosphate buffer $\mathrm{pH} \mathrm{7.5)} \mathrm{and} \mathrm{the} \mathrm{exiting} \mathrm{flow} \mathrm{stream}$ was collected over 5 days (collected volume $\sim 5 \mathrm{~L}$ ), monitoring the reaction outcome by HPLC every $6 \mathrm{~h}$. HPLC analysis showed that the enzymes retained their activity (the conversion was constant, approximately $85 \%$ ) even after 5 days of continuous work. After that time, the flow stream was stopped. This result demonstrates the excellent stability of the new bioreactor under the applied operational conditions (Table 2). Continuous flow synthesis of adenosine (7) resulted in a good space time yield ( $1.8 \mathrm{~g} /$ day) and a biocatalyst productivity of $0.98 \mathrm{mmol}_{\text {product }} / \mathrm{mg}_{\text {enzyme }}$ (defined as mmol of product formed over $24 \mathrm{~h}$ per amount of biocatalyst).

Table 2. Synthesis of adenosine (7) by continuous flow transglycosylation reaction catalyzed by co-immobilized C $p \mathrm{UP}$ and AhPNP: system productivity.

\begin{tabular}{cccc}
\hline $\begin{array}{c}\text { Residence Time } \\
\text { (min) }\end{array}$ & Conversion (\%) & $\begin{array}{c}\text { Space Time Yield } \\
(\mathrm{g} / \text { day) }\end{array}$ & $\begin{array}{c}\text { Catalyst Productivity (24 h) } \\
\text { (mmol } \text { product }_{\text {(mg }} \text { enzyme) }\end{array}$ \\
\hline 1 & 85 & 1.8 & 0.98 \\
\hline
\end{tabular}

Conversion (\%) was monitored over 5 days by sampling the exiting flow stream every 6 h. Each analysis was repeated twice.

The versatility of the bioreactor was evaluated using different sugar donors and sugar acceptors under the conditions set-up for uridine/adenine transglycosylation reaction (Table 3), resulting in conversions between 40 and $76 \%$. 
Table 3. Synthesis of purine ribo- and $2^{\prime}$-deoxyribonucleosides (7-10) by a continuous flow transglycosylation reaction catalyzed by co-immobilized C $p \mathrm{UP}$ and $A h \mathrm{PNP}$.

\begin{tabular}{cccc}
\hline Sugar Donor & Sugar Acceptor & Product & Conversion $^{\mathbf{a}} \mathbf{( \% )}$ \\
\hline $\mathbf{1}(\mathrm{Urd})$ & $\mathbf{5}(\mathrm{Ade})$ & $\mathbf{7}(\mathrm{Ado})$ & $\mathbf{7 6}$ \\
$\mathbf{1}(\mathrm{Urd})$ & $\mathbf{6}(\mathrm{Hpx})$ & $\mathbf{9}(\mathrm{Ino})$ & 45 \\
$\mathbf{2}(\mathrm{dUrd})$ & $\mathbf{5}(\mathrm{Ade})$ & $\mathbf{8}(\mathrm{dAdo})$ & 70 \\
$\mathbf{2}(\mathrm{dUrd})$ & $\mathbf{6}(\mathrm{Hpx})$ & $\mathbf{1 0}(\mathrm{dIno})$ & 50 \\
$\mathbf{3}(\mathrm{Thd})$ & $\mathbf{5}(\mathrm{Ade})$ & $\mathbf{8}(\mathrm{dAdo})$ & 73 \\
$\mathbf{3}(\mathrm{Thd})$ & $\mathbf{6}(\mathrm{Hpx})$ & $\mathbf{1 0}(\mathrm{dIno})$ & 40 \\
\hline
\end{tabular}

${ }^{\text {a }}$ Determined by HPLC: [product area/(product area + substrate area) $\times 100$. Conversions $(\%)$ are the average of two experiments. Experimental conditions: $50 \mathrm{mM}$ phosphate buffer $\mathrm{pH} 7.5$; [sugar donor] = $16 \mathrm{mM}$; [sugar acceptor $]=8 \mathrm{mM}$; residence time $=1 \mathrm{~min} ; \mathrm{T}=28^{\circ} \mathrm{C} ; \mathrm{P}=20 \mathrm{psi}$.

\subsection{Co-Immobilization on EziG ${ }^{T M}$ Carriers in Continuous Flow}

$\mathrm{EziG}^{\mathrm{TM}}$ is a support made of controlled porosity glass particles, which offers excellent flow through properties due to its interconnecting pore structure and incompressible/non-swelling nature $[19,20]$. The particles contain chelated Fe(III) for His-tag binding. Enzymes bind the carrier through a coordination bond. EziG ${ }^{\mathrm{TM}} 1$ (Opal), a hydrophilic carrier, was selected for this study. The flow co-immobilization (glass column i.d.: $10 \mathrm{~mm}$, length: $100 \mathrm{~mm}$; $\mathrm{EziG}^{\mathrm{TM}} 1: 950 \mathrm{mg}$; reactor volume: $3.0 \mathrm{~mL}$ ) was almost quantitative (97\%) in about $30 \mathrm{~min}$ of residence time, resulting in good recovered activities ( $22 \%$ for $C p \mathrm{UP}$ and $51 \%$ for AhPNP). Excellent results were obtained in the model transglycosylation reaction with uridine/adenine, achieving an $84 \%$ conversion in only 1 min of residence time.

\subsection{Continuous Flow Synthesis of Ara-A (11) and Product Isolation}

In order to synthesize ara-A (11), both the glyoxyl-agarose and the $\mathrm{EziG}^{\mathrm{TM}}$ 1-based bioreactors were tested. A stock solution containing the sugar donor $(\mathrm{araU}, 4,16 \mathrm{mM})$ and the sugar acceptor (adenine, 5, $8 \mathrm{mM}$ ) was prepared avoiding any use of organic co-solvent, thus increasing the "greenness" of the protocol and simplifying the product recovery. Residence time was modified with the aim to achieve the highest conversion (Figure 1). Using the glyoxyl-agarose-based bioreactor, $80 \%$ conversion was reached after $4 \mathrm{~h}$ of residence time, whereas, using the EziG ${ }^{\mathrm{TM}} 1$-based bioreactor, a similar conversion was obtained in only $80 \mathrm{~min}$. 
A
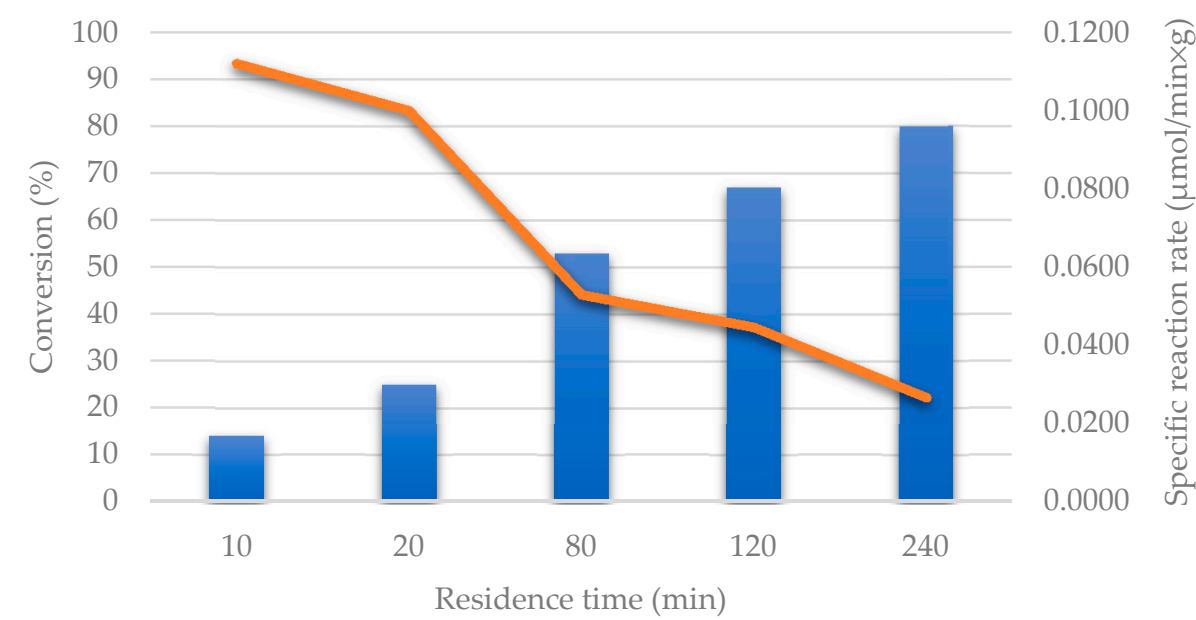

B

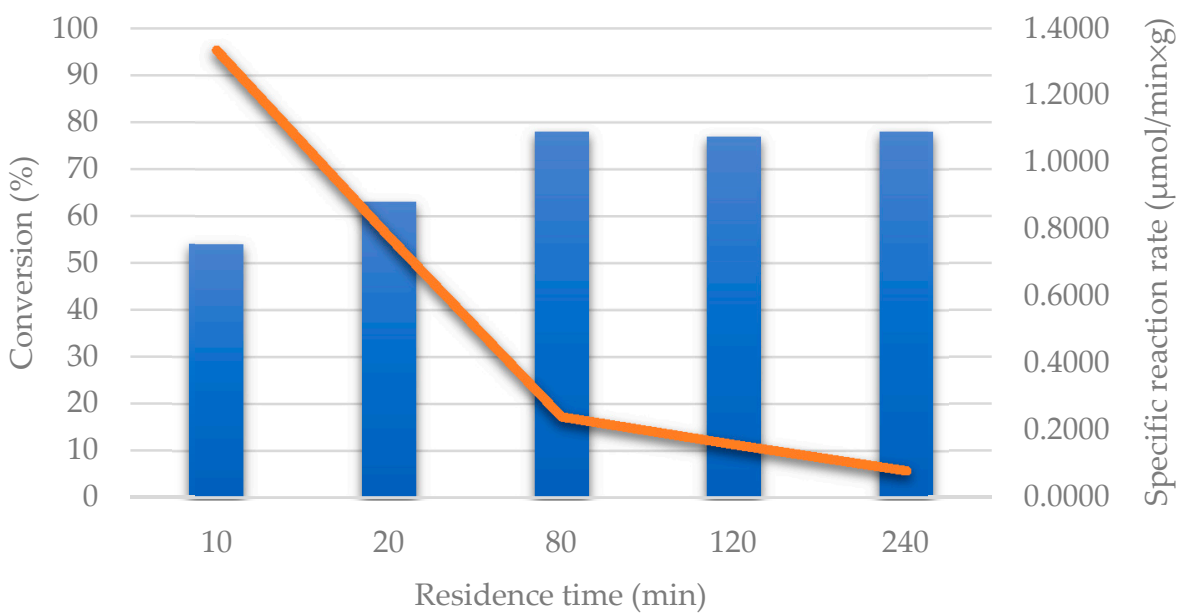

Figure 1. Screening of the residence time for the synthesis of ara-A (vidarabine, 11). (A) enzymes immobilized on glyoxyl-agarose; (B) enzymes immobilized on $\mathrm{EziG}^{\mathrm{TM}} 1$. Experimental conditions: $\left[\right.$ araU] $=16 \mathrm{mM} ;$ [Ade] $=8 \mathrm{mM} ; 50 \mathrm{mM}$ phosphate buffer $\mathrm{pH} \mathrm{7.5;} \mathrm{T}=28^{\circ} \mathrm{C} ; \mathrm{P}=20$ psi. Conversions (\%; blue bars) were determined by HPLC (see Materials and Methods for details). Specific reaction

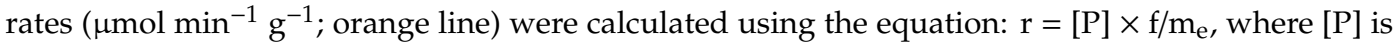
the concentration of the product $(\mu \mathrm{mol} \mathrm{mL}-1)$, $\mathrm{f}$ is the flow rate $\left(\mathrm{mL} \mathrm{min}^{-1}\right)$ and $\mathrm{m}_{\mathrm{e}}$ is the amount of immobilized enzyme (g) [23].

Then, the stability of the EziG ${ }^{\mathrm{TM}} 1$ bioreactor was tested under continuous work, monitoring the reaction outcome every $2 \mathrm{~h}$ by HPLC. The conversion rapidly (after $24 \mathrm{~h}$ ) dropped to less than $10 \%$ and protein was detected in the exiting flow stream. Therefore, in the present study, glyoxyl-agarose was selected as carrier and the bioreactor was used for the continuous flow synthesis of ara-A (11). To this aim, a larger reactor was prepared (glass column i.d.: $15 \mathrm{~mm}$, length: $150 \mathrm{~mm}$; glyoxyl-agarose: $10 \mathrm{~g}$; reactor volume: $10 \mathrm{~mL}$ ) and $1 \mathrm{~L}$ of the solution containing the sugar donor and the sugar acceptor was submitted to the biotransformation, setting the residence time at $120 \mathrm{~min}$ (67\% conversion). The poor water solubility of araA was exploited for product recovery. In detail, the exiting flow stream was directly collected into a cooled vessel to favor the product precipitation. Vidarabine was then recovered by filtration under vacuum, washed with cooled water and dried under vacuum. The reactor was left working for 8 days and then the product was recovered in 55\% isolated yield and very high chemical 
purity ( $>99 \%)$, as determined by HPLC and NMR. Interestingly, even after 8 days of continuous work, the conversion was still about $65 \%$.

\section{Materials and Methods}

All reagents were purchased from Merck Sigma-Aldrich (Milan, Italy). Agarose gel 6B-CL was activated to glyoxyl-agarose as previously reported [24]. TLC analyses were performed using commercial silica gel 60 F254 aluminum sheets. HPLC analyses were performed using a Waters 1525 Binary HPLC Pump, equipped with a Waters 2489 UV-vis detector (Waters, Milford, MA, USA) and an Ascenti C18 column $(25 \mathrm{~cm} \times 4 \mathrm{~mm}, 4 \mu \mathrm{m}$ particle size). The Bradford assay and $\mathrm{C} p \mathrm{UP}$ activity assay were performed using the spectrophotometer Ultrospec 1000 (Pharmacia Biotech, Cologno Monzese, Italy). ${ }^{1} \mathrm{H}-\mathrm{NMR}$ of ara-A (11) in DMSOd6 was recorded on a Varian Gemini $300 \mathrm{MHz}$ spectrometer (Varian, Palo Alto, CA, USA). The continuous flow reactions were performed using either a R2+/R4 series or an E series flow reactor, commercially available from Vapourtec (Cambridge, UK) equipped with Omnifit glass columns with one fixed and one adjustable endfits. Recombinant $C p U P$ and $A h P N P$ were prepared as previously reported [17]. One international unit (IU) corresponds to the amount of enzyme that transforms $1 \mu \mathrm{mol}$ of substrate per minute under specific temperature and $\mathrm{pH}$ values, while the specific activity is defined as units of enzyme activity per milligram of protein.

\subsection{Analytical Methods}

Samples for the standard activity assay of AhPNP (Section 3.6), flow activity assay of AhPNP (Section 3.7), flow activity assay of CpUP (Section 3.8) and flow transglycosylation reaction (Section 3.9) were prepared as reported below. Samples were analyzed by HPLC as follows: injection volume: $10 \mu \mathrm{L}$; mobile phase: $\mathrm{H}_{2} \mathrm{O} / \mathrm{MeOH}$ 9:1; flow rate: $1.0 \mathrm{~mL} \mathrm{~min}^{-1} ; \lambda: 260 \mathrm{~nm}$. Retention times $\left(\mathrm{t}_{\mathrm{R}}\right)$ : thymine $(13)=6.6 \mathrm{~min}$; thymidine $(3)=13.2 \mathrm{~min}$; adenine $(5)=8.9 \mathrm{~min}$; adenosine $(7)=27.8 \mathrm{~min}$; $2^{\prime}$-deoxyadenosine $(\mathbf{8})=26.4 \mathrm{~min}$; uracil $(\mathbf{1 2})=3.6 \mathrm{~min}$; uridine $(\mathbf{1})=4.8 \mathrm{~min} ; 2^{\prime}$-deoxyuridine $(2)=7.1$ $\min ; 2^{\prime}$-deoxyinosine $(\mathbf{1 0})=10.9 \mathrm{~min}$; inosine $(\mathbf{9})=4.7 \mathrm{~min}$; hypoxanthine $(\mathbf{6})=8.2 \mathrm{~min}$. The percentage of conversion was calculated on the basis of the depletion of the sugar acceptor (nucleobase) and monitoring the formation of the nucleoside product: Conversion [\%] = [product area/(product area + base area) $] \times 100$.

\subsection{Immobilization Yields}

The immobilization yields (\%) were determined as: immobilized protein and activity recovery as reported by Sheldon et al. [25] according to the following equations: immobilized protein (\%): (immobilized protein/loaded protein) $\times 100$; activity recovery $(\%)$ : (observed activity of the immobilized enzyme/starting activity) $\times 100$.

\subsection{Co-Immobilization of CpUP and AhPNP on Glyoxyl-Agarose under Flow Conditions}

Glyoxyl-agarose $(0.68 \mathrm{~g}$, volume $0.68 \mathrm{~mL})$ was packed into an Omnifit glass column $(6.6 \mathrm{~mm} \times 100$ $\mathrm{mm}$ ) and the packed-bed reactor was washed with $50 \mathrm{mM}$ carbonate buffer $\mathrm{pH} 10$. A mixture of glycerol $(20 \% \mathrm{v} / \mathrm{v})$ and hypoxanthine $(5 \mathrm{mM})$ in $50 \mathrm{mM}$ carbonate buffer $\mathrm{pH} 10(4.4 \mathrm{~mL})$ was prepared. In order to dissolve hypoxanthine, the suspension was sonicated using a VWR ultrasonic bath $(3 \times 10 \mathrm{~min}$, frequency: $35 \mathrm{Khz})$. To the obtained solution, $4.8 \mathrm{mg}$ of $A h \mathrm{PNP}(156 \mu \mathrm{L})$ were added. The solution was flowed through the column at a flow rate of $0.1 \mathrm{~mL} \mathrm{~min}^{-1}$; the exiting solution was collected and recirculated through the column for $3 \mathrm{~h}$. The residual protein was determined by Bradford assay [22]. Then, a solution of $2.0 \mathrm{mg}$ of $\mathrm{C} p \mathrm{UP}(250 \mu \mathrm{L})$ in $50 \mathrm{mM}$ carbonate buffer $\mathrm{pH} 10(3 \mathrm{~mL})$ was prepared and flowed through the same column at a flow rate of $0.1 \mathrm{~mL} \mathrm{~min}^{-1}$. The exiting solution was collected and recirculated for $3 \mathrm{~h}$. The residual protein was determined by Bradford assay [22]. Chemical reduction of imines was carried out by adding $\mathrm{NaBH}_{4}(14 \mathrm{mg})$ to the recirculating mixture at $0.2 \mathrm{~mL} \mathrm{~min}^{-1}$ for $30 \mathrm{~min}$. The bioreactor was then washed with water for $30 \mathrm{~min}$ at $0.4 \mathrm{~mL} \mathrm{~min}^{-1}$. 


\subsection{Co-Immobilization of CPUP and AhPNP on EziG ${ }^{T M} 1$ (Opal) under Flow Conditions}

EziG $^{\mathrm{TM}} 1(950 \mathrm{mg}, 3.0 \mathrm{~mL})$ was packed into an Omnifit glass column $(10 \mathrm{~mm} \times 100 \mathrm{~mm})$. A solution of $25 \mathrm{mg}$ of $C p \mathrm{UP}$ stock solution $\left(6.16 \mathrm{mg} \mathrm{mL}^{-1}\right)$ and $25 \mathrm{mg}$ of $A h P N P$ stock solution $\left(22.4 \mathrm{mg} \mathrm{mL}^{-1}\right)$ in $20 \mathrm{mM}$ phosphate buffer $\mathrm{pH} 7.5$ and $300 \mathrm{mM} \mathrm{NaCl}$ solution was prepared $(16.7 \mathrm{~mL})$. The solution was flowed at $0.1 \mathrm{~mL} \mathrm{~min}^{-1}$ and recirculated for $2 \mathrm{~h}$. The residual protein was determined by the Bradford assay [22].

\subsection{Standard Activity Assay of CpUP}

The activity of soluble C $p$ UP toward 2'-deoxyuridine (2) was determined as previously reported [21]. Briefly, a solution of $2^{\prime}$-deoxyuridine (2) in $50 \mathrm{mM}$ potassium phosphate buffer pH $7.5(230 \mu \mathrm{L})$ and deionized water $(645 \mu \mathrm{L})$ was prepared. After the addition of the soluble $(5 \mu \mathrm{L}$ of enzyme preparation diluted 1:10) or immobilized $(10 \mathrm{mg})$ enzyme, the mixture was incubated under mechanical stirring. At different times (5 and $10 \mathrm{~min}$ ), samples were withdrawn and $10 \mathrm{M} \mathrm{NaOH}$ $(70 \mu \mathrm{L})$ was added. The increase in absorbance at $297 \mathrm{~nm}$ was then measured.

\subsection{Standard Activity Assay of AhPNP}

The activity of soluble $A h \mathrm{PNP}$ was assessed by measuring the phosphorolysis of inosine (9) as previously reported [21]. Briefly, to a $5 \mathrm{mM}$ solution of inosine (9) in $50 \mathrm{mM}$ phosphate buffer $\mathrm{pH} 7.5$, the soluble enzyme (30 $\mu \mathrm{L}$ of enzyme diluted 1:10) was added and the mixture was incubated under mechanical stirring. At different times ( 5 and $10 \mathrm{~min}$ ), $500 \mu \mathrm{L}$ of the solution were taken and mixed with $500 \mu \mathrm{L}$ of $\mathrm{MeOH}$. The mixture was heated for $5 \mathrm{~min}$ at $95^{\circ} \mathrm{C}$ and then centrifuged $(10 \mathrm{~min}, 13000$ rpm). The supernatant was taken and diluted with a solution of $\mathrm{H}_{2} \mathrm{O} / \mathrm{MeOH}(9: 1)$, in order to obtain $1 \mathrm{mM}$ solution. The sample was then analyzed by HPLC. For the immobilized AhPNP, the same assay was performed by using $20 \mathrm{mg}$ of the immobilized biocatalyst under magnetic stirring. At different times ( 5 and $10 \mathrm{~min}$ ), $500 \mu \mathrm{L}$ of the solution were taken and filtered. The sample was then diluted with a solution of $\mathrm{H}_{2} \mathrm{O} / \mathrm{MeOH}(9: 1)$ in order to obtain a $1 \mathrm{mM}$ solution. The sample was then analyzed by HPLC.

\subsection{Flow Activity Assay of AhPNP}

A solution of inosine $(9,5 \mathrm{~mL}, 20 \mathrm{mM})$ in $50 \mathrm{mM}$ phosphate buffer $\mathrm{pH} 7.5$ was prepared and pumped through the column packed with immobilized AhPNP. The outcome of the reaction at different residence times (i.e., 1, 2.5, 5 and $10 \mathrm{~min}$ ) was analyzed by HPLC.

\subsection{Flow Activity Assay of CpUP}

A solution of $2^{\prime}$-deoxyuridine $(2,5 \mathrm{~mL}, 20 \mathrm{mM})$ in $50 \mathrm{mM}$ phosphate buffer $\mathrm{pH} 7.5$ was prepared and pumped through the column packed with immobilized $C p \mathrm{UP}$. The outcome of the reaction at different residence times (i.e., 1, 2.5, 5 and $10 \mathrm{~min}$ ) was analyzed by HPLC.

\subsection{General Procedure for the Flow Transglycosylation Reaction}

A solution of the sugar donor and the sugar acceptor was prepared in $50 \mathrm{mM}$ phosphate buffer $\mathrm{pH}$ 7.5. In the case of hypoxanthine (6), in order to dissolve it, the suspension was sonicated ( $3 \times 10 \mathrm{~min})$. The temperature was set at $28{ }^{\circ} \mathrm{C}$. The column packed with immobilized C $p$ UP and AhPNP $(0.68 \mathrm{~g}$, $0.68 \mathrm{~mL}$ ) was washed with $50 \mathrm{mM}$ phosphate buffer $\mathrm{pH} 7.5$ at $0.2 \mathrm{~mL} \mathrm{~min}^{-1}$ for $10 \mathrm{~min}$ at atmospheric pressure. The substrate solution $(2.0 \mathrm{~mL})$ was flowed through the bioreactor. Residence times and concentrations were varied as reported in Table 1 . The reaction outcome was monitored by HPLC. A sample of the exiting flow stream $(200 \mu \mathrm{L})$ was diluted with a mixture of $\mathrm{H}_{2} \mathrm{O} / \mathrm{MeOH}(9: 1)$, in order to obtain a sample concentration of $0.1 \mathrm{mM}$, and was used for the analysis. 


\subsection{Synthesis of Vidarabine (11)}

A solution of arabinofuranosyluracil $(4,16 \mathrm{mM})$ and adenine $(5,8 \mathrm{mM})$ was prepared in $50 \mathrm{mM}$ phosphate buffer $\mathrm{pH} 7.5(1 \mathrm{~L})$. The column $(15 \mathrm{~mm} \times 150 \mathrm{~mm})$ packed with immobilized CpUP and AhPNP (10 g, $10 \mathrm{~mL}$ ) was washed with $50 \mathrm{mM}$ phosphate buffer $\mathrm{pH} 7.5$ at $1.0 \mathrm{~mL} \mathrm{~min}^{-1}$ for $30 \mathrm{~min}$. The substrate solution was flowed into the system at $83 \mu \mathrm{L} \mathrm{min}{ }^{-1}$ (residence time: $120 \mathrm{~min}$ ), at $28^{\circ} \mathrm{C}$ and 20 psi for 8 days. The reaction outcome was monitored by HPLC by collecting a sample of the exiting flow stream every $8 \mathrm{~h}$. The exiting solution was collected into a flask, which was then cooled at $4{ }^{\circ} \mathrm{C}$ to favor the product precipitation. The solid was filtered under vacuum, washed with cooled water $(50 \mathrm{~mL})$ and dried under vacuum. Vidarabine (11) was isolated in $55 \%$ yield as a white solid (1.1 g). ${ }^{1} \mathrm{H}-\mathrm{NMR}$ was in agreement with literature data [17].

\section{Conclusions}

The combination of biocatalysis and flow chemistry technology is recognized as an efficient tool for process intensification, as demonstrated by more and more successful examples of industrially relevant processes.

In this frame, we have set-up a biocatalyzed synthesis for the preparation of the antiviral drug vidarabine (11), using a bioreactor in flow. The bioreactor was prepared by in-flow co-immobilization of CpUP and AhPNP on glyoxyl-agarose. The synthesis was scaled-up to gram scale: $1 \mathrm{~g}$ of vidarabine was synthesized and purified in an overall time of 8 days. The system is versatile and, in principle, transferable to the preparation of other nucleoside analogues. Further scale-up could be achieved by simply letting the reactor flow for an extended period of time, without modifying, in any way, the reaction set-up, or by increasing the size of the bioreactor, or again, by working with parallel reactors.

Author Contributions: Conceptualization, L.T., G.S., D.U. and P.C.; methodology, L.T.; investigation, L.T., C.P., F.A., T.B., E.C., F.R., A.P., D.U.; resources, M.T., G.S., D.U., P.C.; data curation, L.T.; writing一original draft preparation, L.T., G.S., D.U. and P.C.; writing-review and editing, L.T., G.S., D.U. and P.C.; supervision, L.T., D.U. and P.C.; project administration, M.T. and P.C.; funding acquisition, M.T. and P.C. All authors have read and agreed to the published version of the manuscript.

Funding: This research was funded by Cariplo Foundation (Italy), call: "Integrated research on industrial biotechnologies and bioeconomy 2016", project BIOFLOW, grant number 2016-0731.

Conflicts of Interest: The authors declare no conflict of interest.

\section{References}

1. Truppo, M.D. Biocatalysis in the pharmaceutical industry: The need for speed. ACS Med. Chem. Lett. 2017, 8, 476-480. [CrossRef] [PubMed]

2. Alcántara, A.R. Biocatalysis and pharmaceuticals: A smart tool for sustainable development. Catalysts 2019, 9, 792. [CrossRef]

3. Woodley, J.M. Accelerating the implementation of biocatalysis in industry. Appl. Microbiol. Biotechnol. 2019, 103, 4733-4739. [CrossRef] [PubMed]

4. Tamborini, L.; Fernandez, P.; Paradisi, F.; Molinari, F. Flow bioreactors as complementary tools for biocatalytic process intensification. Trends Biotechnol. 2018, 36, 73-88. [CrossRef] [PubMed]

5. Contente, M.L.; Farris, S.; Tamborini, L.; Molinari, F.; Paradisi, F. Flow-based enzymatic synthesis of melatonin and other high value tryptamine derivatives: A five-minute intensified process. Green Chem. 2019, 21, 3263-3266. [CrossRef]

6. De Vitis, V.; Dall'Oglio, F.; Tentori, F.; Contente, M.L.; Romano, D.; Brenna, E.; Tamborini, L.; Molinari, F. Bioprocess intensification using flow reactors: Stereoselective oxidation of chiral 1,3-diols with immobilized Acetobacter aceti. Catalysts 2019, 9, 208. [CrossRef]

7. Contente, M.L.; Dall'Oglio, F.; Tamborini, L.; Molinari, F.; Paradisi, F. Highly efficient oxidation of amines to aldehydes via flow-based biocatalysis. ChemCatChem 2017, 9, 3843-3848. [CrossRef] 
8. De Vitis, V.; Dall'Oglio, F.; Pinto, A.; De Micheli, C.; Molinari, F.; Conti, P.; Romano, D.; Tamborini, L. Chemoenzymatic synthesis in flow reactors: A rapid and convenient preparation of Captopril. Chem. Open 2017, 6, 668-673. [CrossRef]

9. Devine, P.N.; Howard, R.M.; Kumar, R.; Thompson, M.P.; Truppo, M.D.; Turner, N.J. Extending the application of biocatalysis to meet the challenges of drug development. Nat. Rev. Chem. 2018, 2, 409-421. [CrossRef]

10. Vorbrueggen, H.; Ruh-Pohlenz, C. Synthesis of nucleosides. Org. React. 2000, 55. [CrossRef]

11. Mikhailopulo, I.; Miroshnikov, A.I. Biologically important nucleosides: Modern trends in biotechnology and application. Mendeleev Commun. 2011, 21, 57-68. [CrossRef]

12. Ubiali, D.; Serra, C.D.; Serra, I.; Morelli, C.F.; Terreni, M.; Albertini, A.M.; Manitto, P.; Speranza, G. Produc-tion, characterization and synthetic application of a purine nucleoside phosphorylase from Aeromonas hy-drophila. Adv. Synth. Catal. 2012, 354, 96-104. [CrossRef]

13. Zhou, X.; Szeker, K.; Jiao, L.-Y.; Oestreich, M.; Mikhailopulo, I.A.; Neubauer, P. Synthesis of 2,6-dihalogenated purine nucleosides by thermostable nucleoside phosphorylases. Adv. Synth. Catal. 2015, 357, 1237-1244. [CrossRef]

14. Zhou, X.; Yan, W.; Zhang, C.; Yang, Z.; Neubauer, P.; Mikhailopulo, I.A.; Huang, Z. Biocatalytic synthesis of seleno-, thio- and chloro-nucleobase modified nucleosides by thermostable nucleoside phosphorylases. Catal. Commun. 2019, 121, 32-37. [CrossRef]

15. Rabuffetti, M.; Bavaro, T.; Semproli, R.; Cattaneo, G.; Massone, M.; Morelli, C.F.; Speranza, G.; Ubiali, D. Synthesis of Ribavirin, Tecadenoson, and Cladribine by enzymatic transglycosylation. Catalysts 2019, 9, 355. [CrossRef]

16. Fernández-Lucas, J.; Camarasa Rius, M.J. Enzymatic and Chemical Synthesis of Nucleic Acid Derivatives, 1st ed.; Wiley-VCH Verlag GmbH \& Co. KGaA: Weinheim, Germany, 2018; pp. 1-325.

17. Serra, I.; Daly, S.; Alcantara, A.R.; Bianchi, D.; Terreni, M.; Ubiali, D. Redesigning the synthesis of Vidarabine via a multienzymatic reaction catalyzed by immobilized nucleoside phosphorylases. RSC Adv. 2015, 5, 23569-23577. [CrossRef]

18. Robescu, M.S.; Serra, I.; Terreni, M.; Ubiali, D.; Bavaro, T. A multi-enzymatic cascade reaction for the synthesis of vidarabine $5^{\prime}$-monophosphate. Catalysts 2020, 9, 60. [CrossRef]

19. Engelmark Cassimjee, K.; Federsel,H.-J. EziG: A universal platform for enzyme immobilization. In Biocatalysis: An Industrial Perspective, 1st ed.; De Gonzalo, G., Domínguez de María, P., Eds.; RSC Publishing: Cambridge, UK, 2018; pp. 345-362. [CrossRef]

20. Thompson, M.P.; Peñafiel, I.; Cosgrove, S.C.; Turner, N.J. Biocatalysis using immobilized enzymes in continuous flow for the synthesis of fine chemicals. Org. Process. Res. Dev. 2019, 23, 9-18. [CrossRef]

21. Serra, I.; Ubiali, D.; Piškur, J.; Christoffersen, S.; Lewkowicz, E.S.; Iribarren, A.M.; Albertini, A.M.; Terreni, M. Developing a collection of immobilized nucleoside phosphorylases for the preparation of nucleoside analogues: Enzymatic synthesis of arabinosyladenine and $2^{\prime}, 3^{\prime}$-dideoxyinosine. ChemPlusChem 2013, 78, 157-165. [CrossRef]

22. Bradford, M.M. A rapid and sensitive method for the quantitation of microgram quantities of protein utilizing the principle of protein-dye binding. Anal. Biochem. 1976, 27, 248-254. [CrossRef]

23. Zambelli, P.; Tamborini, L.; Cazzamalli, S.; Pinto, A.; Arioli, S.; Balzaretti, S.; Plou, F.J.; Fernandez-Arrojo, L.; Molinari, F.; Conti, P.; et al. An efficient continuous flow process for the synthesis of a non-conventional mixture of fructooligosaccharides. Food Chem. 2016, 190, 607-613. [CrossRef] [PubMed]

24. Guisàn, J.M. Aldehyde-agarose gels as activated supports for immobilization-stabilization of enzymes. Enzym. Microb. Technol. 1988, 10, 375-382. [CrossRef]

25. Sheldon, R.A.; van Pelt, S. Enzyme immobilisation in biocatalysis: Why, what and how. Chem. Soc. Rev. 2013, 42, 6223-6235. [CrossRef] [PubMed]

Sample Availability: Samples of vidarabine are available from the authors. 